\title{
Regulation of Rat Cortex Function by D1 Dopamine Receptors in the Striatum
}

\author{
Heinz Steiner and Stephen T. Kitai \\ Department of Anatomy and Neurobiology, University of Tennessee, College of Medicine, Memphis, Tennessee 38163
}

Interactions between the basal ganglia and the cerebral cortex are critical for normal goal-directed behavior. In the present study, we used immediate-early genes (c-fos, zif 268) as functional markers to investigated how basal ganglia output altered by stimulation/blockade of D1 dopamine receptors in the striatum affects cortical function. Systemic administration of the mixed D1/D2 receptor agonist apomorphine (3 $\mathrm{mg} / \mathrm{kg})$ increased immediate-early gene expression in the striatum and throughout most of the cortex. Unilateral intrastriatal infusion of the selective D1 receptor antagonist SCH-23390 $(0.5-10 \mu \mathrm{g})$ blocked this response bilaterally in striatum and cortex in a dose-dependent manner. Even apparently regionally restricted blockade of striatal D1 receptors attenuated gene expression throughout striatum and cortex in both hemispheres. Intrastri- atal administration of the D1 antagonist inhibited apomorphineinduced sniffing/whisking, whereas other motor behaviors were unaffected. To determine whether such changes in cortical gene expression could reflect altered cortical function, we examined the effects of blocking striatal D1 receptors on whisker stimulationevoked immediate-early gene expression in the sensorimotor cortex. Apomorphine increased sensory stimulation-evoked gene expression in the barrel cortex, and intrastriatal infusion of $\mathrm{SCH}-23390$ attenuated this effect. These results suggest that stimulation of D1 dopamine receptors in the striatum exerts a widespread facilitatory effect on cortical function.

Key words: dopamine; striatum; basal ganglia; cortex; barrel; c-fos; zif 268; immediate-early genes
Abnormal interactions between the basal ganglia and the cerebral cortex have been implicated in various brain disorders, including Parkinson's disease, schizophrenia, and drug addiction (Albin et al., 1989; Carlsson and Carlsson, 1990; DeLong, 1990; Graybiel, 1997; Sarter and Bruno, 1999). Moreover, deficient dopamine function in the striatum is perceived at the core of several of these disorders (Wise and Bozarth, 1987; Albin et al., 1989; DeLong, 1990; Hyman and Nestler, 1996; Pierce and Kalivas, 1997). The striatum (caudate putamen and nucleus accumbens) receives afferents from all parts of the cortex and projects, via basal ganglia output nuclei and thalamus, back to the cortex (Alexander et al., 1990; Gerfen, 1992; Parent and Hazrati, 1995; Gerfen and Wilson, 1996; Smith et al., 1998). Striatal output is conveyed by two pathways, the so-called "indirect" pathway, which projects via globus pallidus (external pallidum in primates) and subthalamic nucleus to the output nuclei (substantia nigra and entopeduncular nucleus/internal pallidum), and the "direct" or "striatonigral" pathway, which sends axons directly to substantia nigra and/or entopeduncular nucleus. Both of these pathways are regulated by dopamine.

Cellular responses used to study the effects of dopamine receptor stimulation in striatal projection neurons and resulting changes in target areas include the expression of immediate-early genes, such as c-fos and zif 268 (for review, see Steiner and Gerfen, 1998). For example, it has been shown that mixed D1/D2

\footnotetext{
Received Jan. 4, 2000; revised March 2, 2000; accepted March 13, 2000.

This work was supported by the National Parkinson Foundation and United States Public Health Service Grants DA11261 (H.S.), NS26473, and NS20702 (S.T.K.). We thank Lucinda Del Mar for excellent technical assistance, and P. Melzer and D. Plenz for discussions.

Correspondence should be addressed to Heinz Steiner, Department of Cellular and Molecular Pharmacology, Finch University of Health Sciences/The Chicago Medical School, 3333 Green Bay Road, North Chicago, IL 60064. E-mail: steinerh@ finchcms.edu.

Copyright (C) 2000 Society for Neuroscience $\quad 0270-6474 / 00 / 205449-12 \$ 15.00 / 0$
}

or indirect dopamine receptor agonists, such as apomorphine or cocaine, induce immediate-early genes in striatonigral neurons (Cenci et al., 1992; Johansson et al., 1994; Kosofsky et al., 1995), a response that is mediated by D1 receptors (Graybiel et al., 1990; Steiner and Gerfen, 1995; Drago et al., 1996). Such results have been taken to indicate that stimulation of striatal D1 receptors facilitates activity in the direct, striatonigral pathway, which would enhance GABA release in target nuclei (You et al., 1994), inhibit basal ganglia output, and thus disinhibit thalamocortical activity (Albin et al., 1989; Chevalier and Deniau, 1990). Consistent with this notion, several studies showed that dopamine agonists produce increased immediate-early gene expression in the cortex (Dilts et al., 1993; Steiner and Gerfen, 1994; Wang and McGinty, 1995; LaHoste et al., 1996; Berke et al., 1998). However, the exact role of striatal dopamine receptors remains uncertain. First, the above studies used systemic dopamine agonist treatments, precluding conclusions regarding the location of the involved receptors. There is evidence, for example, that dopamine receptors in the substantia nigra contribute to the regulation of basal ganglia output (Waszcak and Walters, 1983; Abercrombie and DeBoer, 1997). Second, electrophysiological evidence for D1 receptor-mediated facilitation of striatonigral activity is equivocal (Cepeda and Levine, 1998; Kiyatkin and Rebec, 1999).

To investigate the effects of dopamine action in the striatum on cortical function, we have assessed immediate-early gene expression in the cortex after intrastriatal drug administration. In the present study, we examined the role of striatal D1 receptors in apomorphine-induced gene expression in different cortical areas. To determine whether such changes in gene expression could reflect alterations in cortical function, we also assessed the effects of striatal D1 receptor stimulation on sensory-evoked gene expression in the sensorimotor cortex. 

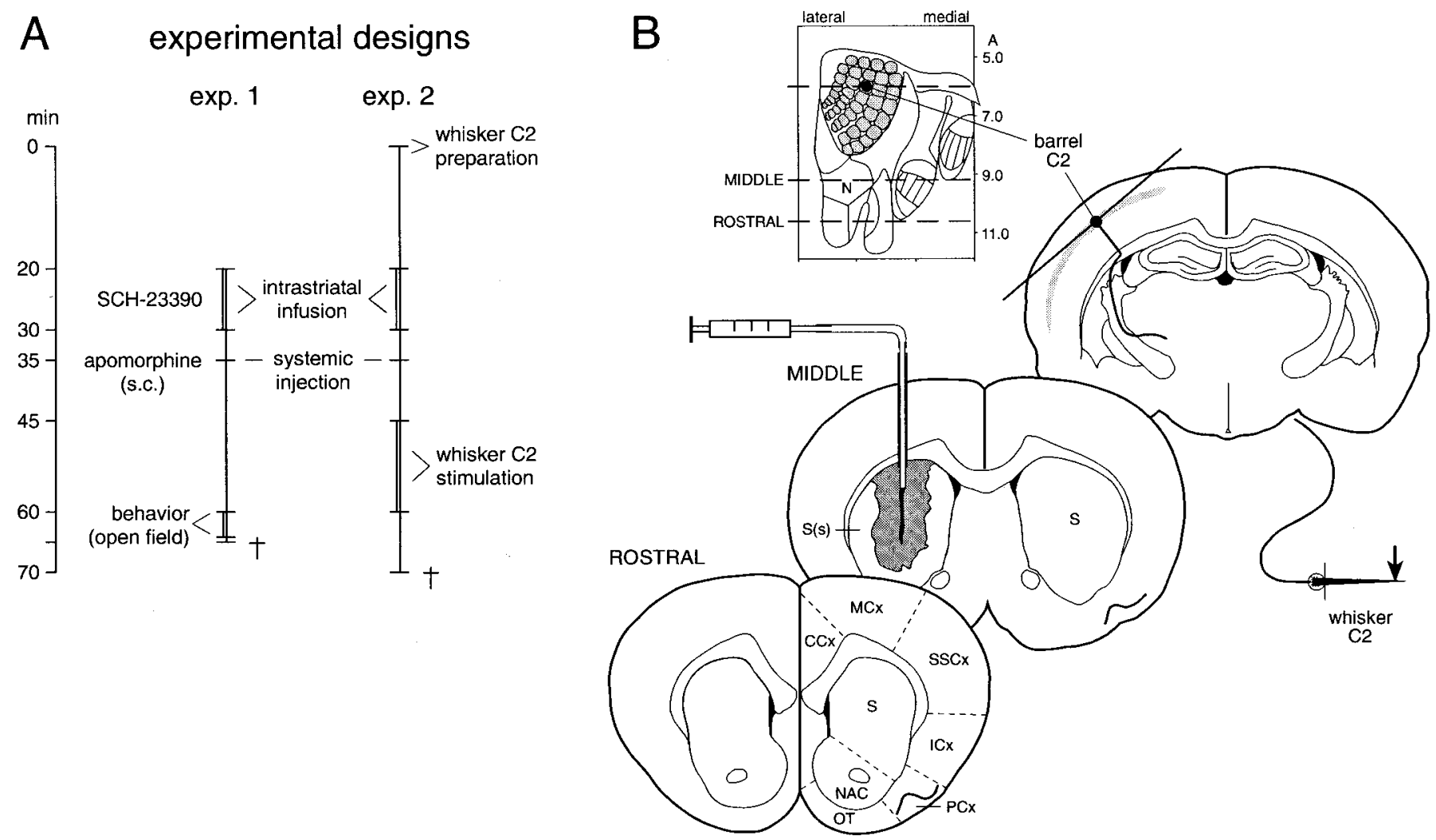

Figure 1. Experimental procedures. A, Time lines for the procedures in experiments 1 and 2. In experiment 1, rats received an inf usion of the D1 receptor antagonist SCH-23390 (0-10 $\mu \mathrm{g}$ in $1 \mu \mathrm{l}$ over $10 \mathrm{~min})$ into the right striatum, followed by systemic administration of the D1/D2 receptor agonist apomorphine ( $3 \mathrm{mg} / \mathrm{kg}$, s.c.). Twenty-five minutes later, their behavior was recorded for $4 \mathrm{~min}$ in an open-field test. In experiment 2 , under light Metofane anesthesia, the left whisker $\mathrm{C} 2$ was equipped with a steel filament, and the other mystacial whiskers were clipped close to the skin. Approximately $20 \mathrm{~min}$ later, rats received an intrastriatal inf usion of SCH-23390 (0-10 $\mu \mathrm{g})$, followed by an injection of apomorphine (3 mg/kg). Whisker C2 was stimulated by a pulsating magnetic field for $15 \mathrm{~min}$, starting $10 \mathrm{~min}$ after the apomorphine administration. Brains were collected $30-35$ min after apomorphine injection. $B$, Schematic diagrams depicting the areas in which gene expression was measured. Results are reported for areas in coronal sections from a rostral striatal level (at $\sim 10.6 \mathrm{~mm}$ rostral to the interaural line; Paxinos and Watson, 1986) and a middle striatal level (9.2 mm) that contained the cannula track (experiments 1 and 2), as well as for the barrel $\mathrm{C} 2$ in tangential sections through layer IV of the barrel cortex (experiment 2). In rostral sections, gene expression was assessed in the striatum $(S)$, nucleus accumbens $(N A C)$, olfactory tubercle $(O T)$, and in the cingulate $(C C x)$, motor $(M C x)$, somatosensory $(S S C x)$, insular $(I C x)$, and piriform cortex $(P C x)$. In middle sections, gene expression was measured across the total striatal area $(S)$ and, for animals that received $0.5 \mu \mathrm{g}$ of $\mathrm{SCH}-23390$, in the area surrounding the site of primary drug action [surrounding area $S(s)$ ], or for the other groups and the noninfused side, in a corresponding, averaged "surrounding" area. The schematic representation of the rat somatosensory cortex (top left; modified from Chapin and Lin, 1984) depicts the approximate rostrocaudal positions of the rostral and middle striatal levels and barrel C2. $N$, Nose area.

\section{MATERIALS AND METHODS}

Subjects. Male Sprague Dawley rats (Sasco, St. Louis, MO), 170-230 gm at the beginning of the experiments, were housed in groups of three to four under standard laboratory conditions. The animals had access to food and water ad libitum and were maintained under a $12 \mathrm{hr}$ light/dark cycle. All experiments were performed between 1:00 P.M. and 5:00 P.M.

Implantation of guide cannulas. Rats were anesthetized with Equithesin $(4.0 \mathrm{ml} / \mathrm{kg})$ and placed in a David Kopf Instruments (Tujunga, CA) stereotaxic frame. A guide cannula (26 gauge, stainless steel; Plastics One, Roanoke, VA) was lowered into the right striatum and fixed to the skull with acrylic cement. The coordinates used for the tip of the guide cannula were (relative to bregma): anterior, +0.4; lateral, 3.0; ventral, -4.0 (Paxinos and Watson, 1986). The guide cannula was occluded with a "dummy cannula" of the same length. Rats were then allowed to recover for 1 week. One day before the infusion, the dummy cannula was replaced with a longer dummy cannula that protruded $2.5 \mathrm{~mm}$ beyond the tip of the guide cannula. This procedure reduces the probability of acute damage by the infusion cannula (33 gauge, $1 \mathrm{~mm}$ longer than the guide cannula), which can cause massive induction of immediate-early genes in cortex and striatum.
Drugs and injection procedures. The $\mathrm{D} 1$ dopamine receptor antagonist SCH-23390 $[R(+)-S C H-23390$ hydrochloride; Research Biochemicals, Natick, MA] (0, 0.5, and $10 \mu \mathrm{g}$ in $1 \mu \mathrm{l}$ of saline; $n=4-6$ each) was infused into the striatum in freely moving animals (Fig. 1). The infusion was performed with a pump at a rate of $0.1 \mu \mathrm{l} / \mathrm{min}$. After the infusion, the cannula was left in place for an additional $2.5 \mathrm{~min}$ to allow for diff usion of the drug. The rat was then returned to the home cage. Fifteen minutes after beginning of the intrastriatal inf usion, the animals received a systemic injection of the D1/D2 receptor agonist apomorphine (apomorphine hydrochloride; Sigma, St. Louis, MO) (3 mg/kg, s.c.; in $0.02 \%$ ascorbic acid, $1 \mathrm{ml} / \mathrm{kg}$ ). Controls received an intrastriatal infusion of vehicle or $10 \mu \mathrm{g}$ of SCH-23390, followed by a vehicle injection.

Behavioral test (experiment 1). Drug-induced behavior was observed during the intrastriatal infusion and subsequently in the home cage. In addition, in experiment 1 , behavioral effects were measured in a novel open field $(60 \times 60 \times 40 \mathrm{~cm}$, with lines dividing the floor into $3 \times 3$ squares) during min 26-29 after apomorphine administration. The behavior was videotaped and assessed from the tapes by an experimenter who was unaware of the pharmacological treatment. Behavioral analysis started $30 \mathrm{sec}$ after the animal was placed into the center of the open 
field. The following parameters were determined by counting the number of events: line crossings with all four feet (measure for distance traveled) and half turns (diameter, $<20 \mathrm{~cm}$ ) to either side. In addition, the occurrence of forelimb movements (during locomotion, rearing, turning, or shifting; "stepping") and of intense, repetitive whisking/sniffing were measured by using a time sampling procedure (behavioral item present or absent during a $5 \mathrm{sec}$ interval every $10 \mathrm{sec})$.

Whisker stimulation (experiment 2). Physiological stimulation of whiskers in rats evokes immediate-early gene expression in the contralateral somatosensory cortex (Mack and Mack, 1992; Melzer and Steiner, 1997). Although present throughout the stimulated barrel column, such gene induction is most prominent in layer IV and is restricted to some subpopulations of neurons in that layer (Melzer and Steiner, 1997). By analogy to stimulation-induced expression of zif 268 mRNA in the visual cortex (Chaudhuri et al., 1995) and of BDNF mRNA in the barrel cortex (Rocamora et al., 1996), the responsive neurons may include pyramidal and spiny stellate cells but not GABA neurons.

In experiment 2, one whisker (whisker $\mathrm{C} 2$ on the left side) was stimulated. Stimulation procedures have been described in detail previously (Melzer and Steiner, 1997). In short (Fig. 1A), 45 min before the start of the stimulation (i.e., 20 min before the intrastriatal infusion), the rat was lightly anesthetized by Metofane. A steel filament (length, $6 \mathrm{~mm}$; diameter, $0.3 \mathrm{~mm}$ ) was then glued to whisker C2 with SuperGlue (center of filament $\sim 10 \mathrm{~mm}$ from the skin). The distal end of the whisker was clipped, and all other mystacial whiskers on both sides of the face were clipped close to the skin. The rat was then allowed to recover. Whisker $\mathrm{C} 2$ was stimulated by exposing the rat to a pulsating magnetic field (Van der Loos stimulator; Melzer et al., 1985). The magnetic field (mean strength, $10.8 \mathrm{mT}$, rms) was produced by a copper coil linked to a solid state relay [built by George Dold, Research Services Branch, National Institute of Mental Health (NIMH), Bethesda, MD; based on the design by Melzer et al., 1985]. With the longitudinal axis of the magnetic field oriented horizontally, the field pulses mostly deflect the whiskers in rostrocaudal direction. A pulse rate of $\sim 8 \mathrm{~Hz}$ was chosen to mimic the whisking frequency of a whisking (sniffing) rat (Welker, 1964). The awake rat was placed into the acrylic chamber (cylinder, $15 \mathrm{~cm}$ in length, $14 \mathrm{~cm}$ in diameter) of the stimulator, stimulated for $15 \mathrm{~min}$, and killed 10 min later.

Tissue preparation. Animals were killed with $\mathrm{CO}_{2} 30 \mathrm{~min}$ (experiment 1) or $35 \mathrm{~min}$ (experiment 2) after apomorphine administration. The brain was rapidly removed, frozen in isopentane cooled on dry ice, and stored at $-20^{\circ} \mathrm{C}$ until cryostat sectioning. Coronal sections $(12 \mu \mathrm{m})$ through the striatum (experiment 1) or tangential sections through the somatosensory cortex followed by coronal sections through the striatum (experiment 2) were collected. Sections were thaw-mounted onto glass slides twice coated with gelatin, dried on a warm plate, and stored at $-20^{\circ} \mathrm{C}$. For further processing, the slides were first warmed to room temperature, then fixed in $4 \%$ paraformaldehyde (in $0.9 \%$ saline) for 10 min, and incubated in a fresh solution of $0.25 \%$ acetic anhydride in $0.1 \mathrm{M}$ triethanolamine and $0.9 \%$ saline, $\mathrm{pH} 8.0$, for $10 \mathrm{~min}$. Then the slidemounted sections were dehydrated, defatted for $2 \times 5 \mathrm{~min}$ in chloroform, rehydrated, and air-dried. The sections were stored at $-20^{\circ} \mathrm{C}$ until hybridization. Every sixth tangential section was stained for cytochrome oxidase activity to locate barrel C2 in layer IV (Melzer and Steiner, 1997). Adjacent sections were used for hybridization.

In situ hybridization histochemistry. Oligonucleotide probes (48-mers; Life Technologies, Grand Island, NY) were labeled with $\left[{ }^{35} \mathrm{~S}\right] \mathrm{dATP}$ as described previously (Steiner and Gerfen, 1993). The c-fos probe was complementary to bases 1227-1274 (GenBank accession number $\mathrm{X} 06769$ ) and the zif 268 probe to bases 352-399 (GenBank accession number M18416). Labeled probe $\left(\sim 3 \times 10^{6} \mathrm{cpm}\right)$ in $100 \mu \mathrm{l}$ of hybridization buffer was added to each slide. The sections were coverslipped and incubated overnight at $37^{\circ} \mathrm{C}$. After incubation, the slide-mounted sections were first rinsed in four washes of $1 \times$ saline citrate $(150 \mathrm{~mm}$ sodium chloride and $15 \mathrm{~mm}$ sodium citrate). They were then washed three times for $20 \mathrm{~min}$ each in $2 \times$ saline citrate $-50 \%$ formamide at $40^{\circ} \mathrm{C}$, followed by two washes for $30 \mathrm{~min}$ each in $1 \times$ saline citrate at room temperature. After a brief water rinse, the sections were air-dried and then apposed to x-ray film (X-Omat; Eastman Kodak, Rochester, NY) for 2-3 weeks.

Analysis of autoradiograms. In both experiments, coronal sections collected at three rostrocaudal levels through the striatum were examined (Fig. $1 B$ ): a rostral level (at $\sim 10.6 \mathrm{~mm}$ rostral to the interaural line; Paxinos and Watson, 1986), a caudal level $(8.0 \mathrm{~mm})$, and a midstriatal level (at $\sim 9.2 \mathrm{~mm}$ ) that contained the cannula track. In experiment 2 ,
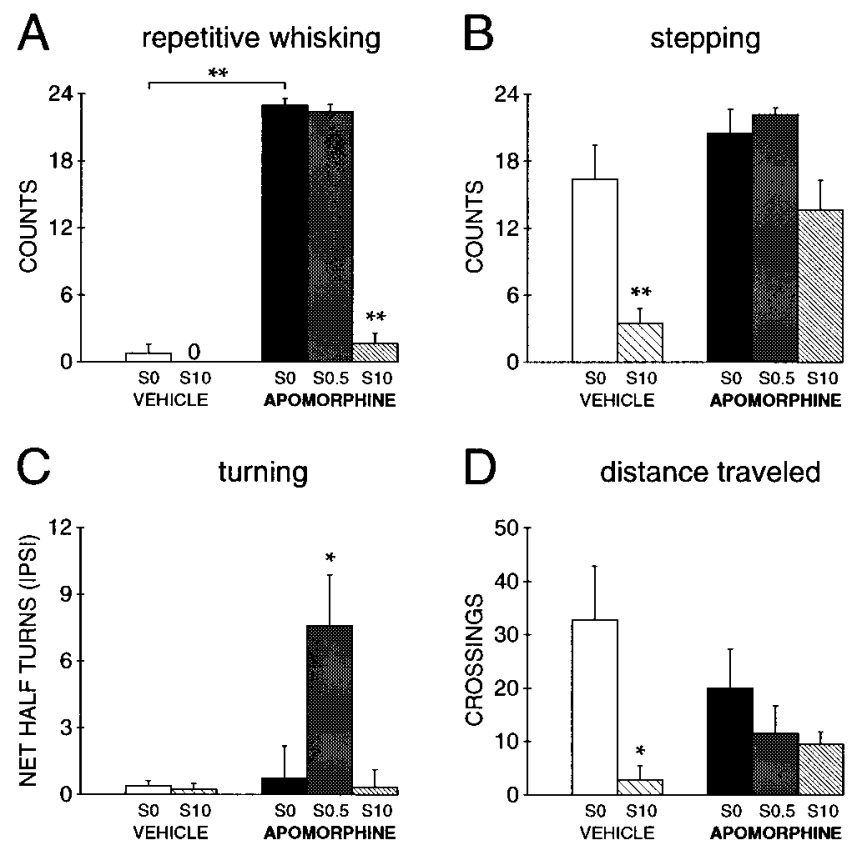

D distance traveled

Figure 2. Open-field behavior after dopamine agonist/antagonist treatments. The behavior was videotaped for $4 \mathrm{~min}$, starting $25 \mathrm{~min}$ after apomorphine administration. Assessed from the tapes were repetitive whisking/sniffing $(A)$, stepping $(B)$, turning $(C)$, and distance traveled $(D)$. Whisking/sniffing and stepping (foreleg movements during locomotion, rearing, turning, or shifting) were judged as present or absent during a 5 sec period every $10 \mathrm{sec}$, and the present counts are shown (mean \pm SEM). Turning is presented as net half turns toward the side of infusion (ipsi). Distance traveled was assessed by counting the number of lines crossed with all four feet. Rats received an intrastriatal infusion of SCH-23390 [0 (SO), $0.5 \mu \mathrm{g}(S O .5)$, or $10 \mu \mathrm{g}(S 10) ; n=4-6$ each), followed by an injection of apomorphine $\left(3 \mathrm{mg} / \mathrm{kg}\right.$, s.c.) or vehicle. ${ }^{*} p<0.05,{ }^{* *} p<0.01$ versus $S O$.

gene expression was also assessed in tangential sections through the somatosensory cortex that were adjacent to sections containing barrel C2 (layer IV), as determined by cytochrome oxidase histochemistry.

Gene expression was measured in the following areas (Fig. $1 B$ ): rostral striatal level, in striatum, nucleus accumbens, olfactory tubercle, cingulate cortex, "motor" cortex (Fr1, Fr2, Fr3; Paxinos and Watson, 1986), somatosensory cortex (Par1), insular cortex (including claustrum), and piriform cortex; middle striatal level, in total striatum ("total area") and the cortical regions mentioned above. In addition, for the group that received an intrastriatal infusion of $0.5 \mu \mathrm{g}$ of SCH-23390, gene expression was measured in the striatum surrounding the site of primary drug action (see Figs. 3, 4) ("surrounding area"). For the other groups and the noninf used side, an area corresponding to the average surrounding area was used. Furthermore, in experiment 2, gene expression was measured in barrel $\mathrm{C} 2$ and in the four surrounding barrels $(\mathrm{C} 1, \mathrm{C} 3, \mathrm{~B} 2$, and D2).

Levels of gene expression were determined by densitometry on film autoradiograms, using a Macintosh-based image analysis system (NIH Image; Wayne Rasband, NIMH). "Mean density" values presented are background-corrected: for coronal sections, mean density ${ }_{\text {gray matter }}$ minus

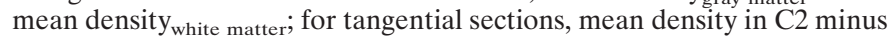
averaged mean density in surrounding barrels. Drug effects were determined with two-factor ANOVAs, followed by post hoc one-factor ANOVAs and Dunnett's tests to describe differences between individual groups. The illustrations of film autoradiograms displayed in Figures 3, 4, and 6 are based on computer-generated images and are contrastenhanced where necessary. Maximal hybridization signal is black.

\section{RESULTS}

\section{Experiment 1}

Behavioral effects

In the open-field test, intrastriatal infusion of the D1 receptor antagonist SCH-23390 alone significantly reduced the distance 


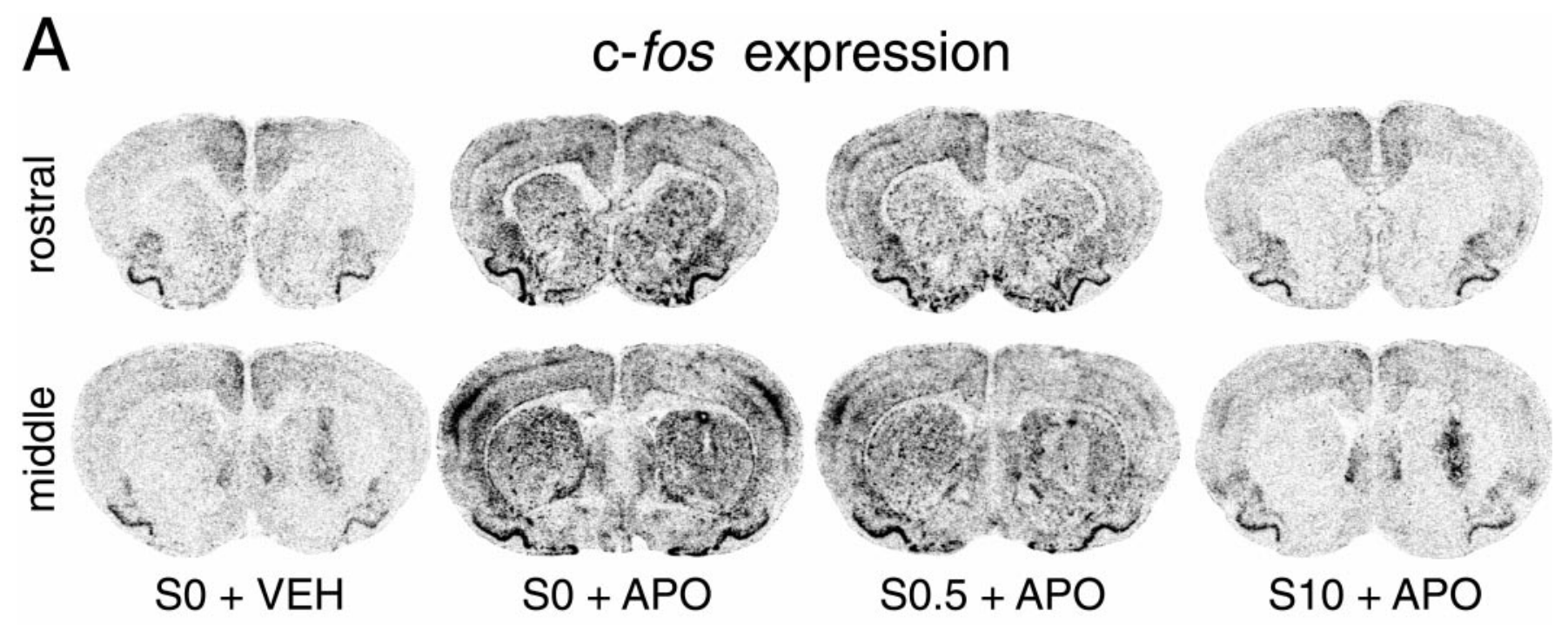

B

middle striatum surrounding
area
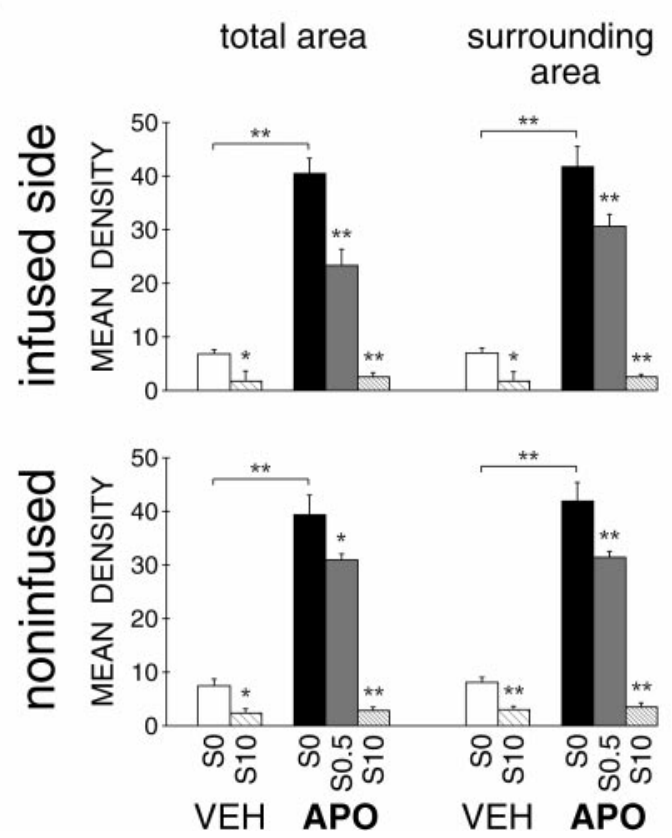

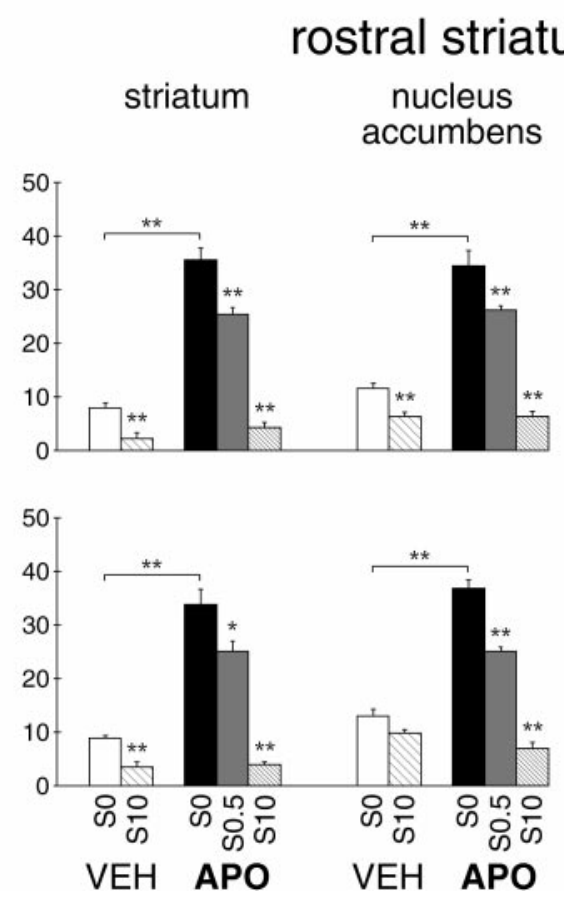

rostral striatum

olfactory
tubercle
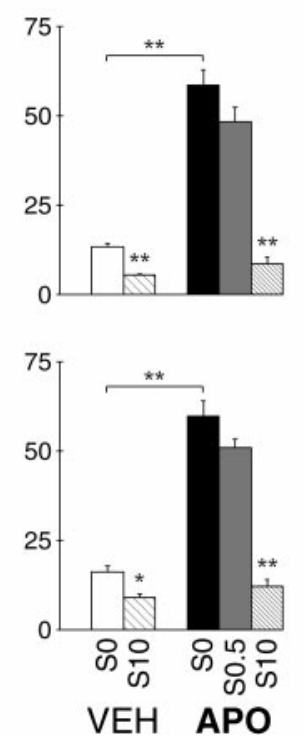

Figure 3. Expression of c-fos mRNA in the striatum, nucleus accumbens, olfactory tubercle, and cortex after dopamine agonist/antagonist treatments. $A$, Illustrations of film autoradiograms show c-fos expression in coronal sections from rostral (top) and middle (bottom) striatal levels in rats that received an infusion of vehicle $(S O), 0.5 \mu \mathrm{g}(S O .5)$, or $10 \mu \mathrm{g}$ of SCH-23390 (S10) into the right striatum before an injection of vehicle (VEH) or apomorphine (3 $\mathrm{mg} / \mathrm{kg}$, s.c.; $A P O)$. B, Mean density values (mean $\pm \mathrm{SEM}$, arbitrary units) measured in the striatum, nucleus accumbens, and olfactory tubercle on the infused (top) and noninfused (bottom) sides, at middle or rostral striatal levels, are shown for the above treatment groups $(n=4-6$ each). For areas, see Figure 1. ${ }^{*} p<0.05,{ }^{* *} p<0.01$.

traveled and the amount of foreleg movements (stepping), as these rats showed very little activity (Fig. 2). Apomorphine produced intense, repetitive sniffing or whisking that was characterized by continuous snout contact with floor and walls as described previously (Szechtman et al., 1982). The higher $(10 \mu \mathrm{g})$, but not the lower $(0.5 \mu \mathrm{g})$, dose of the D1 antagonist almost completely blocked apomorphine-induced sniffing/whisking (Fig. 2). In contrast, neither the amount of stepping nor the distance traveled were significantly reduced by D1 antagonist plus apomorphine treatments. Rats that received an intrastriatal infusion of $0.5 \mu \mathrm{g}$ of SCH-23390, but not those that received $10 \mu \mathrm{g}$, before apomor- phine showed turning behavior toward the side of the infusion during the open-field test (Fig. 2).

Gene expression in the striatum, nucleus accumbens, and olfactory tubercle

Figures 3 and 4 depict the effects of apomorphine and SCH-23390 on immediate-early gene expression at the rostral and middle striatal levels. Similar results were obtained for the caudal striatum (data not shown). Systemic administration of apomorphine produced a robust increase in c-fos and zif 268 expression in the striatum, nucleus accumbens, and olfactory tubercle (Figs. 3, 4). 

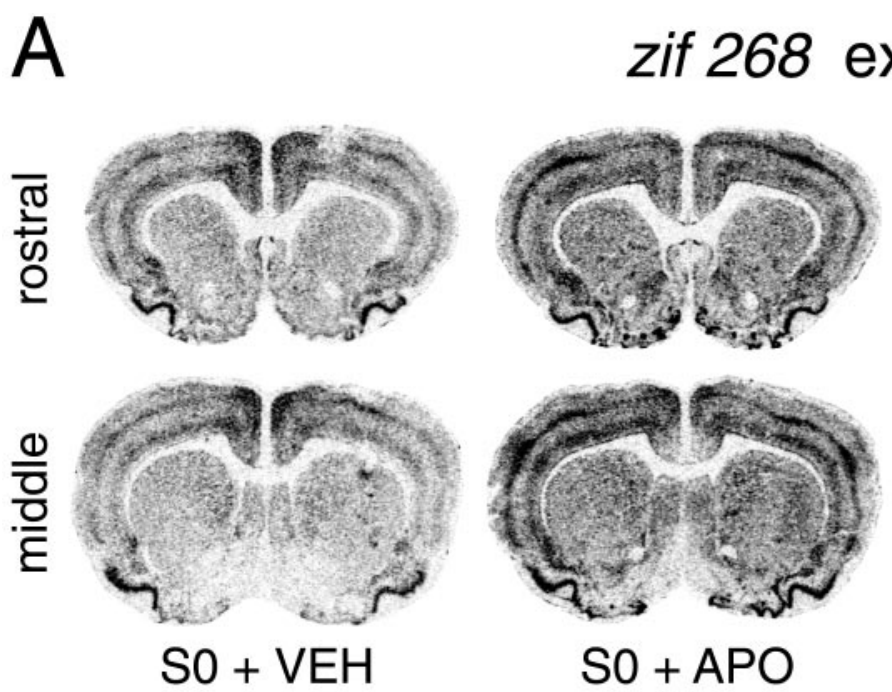

expression

B
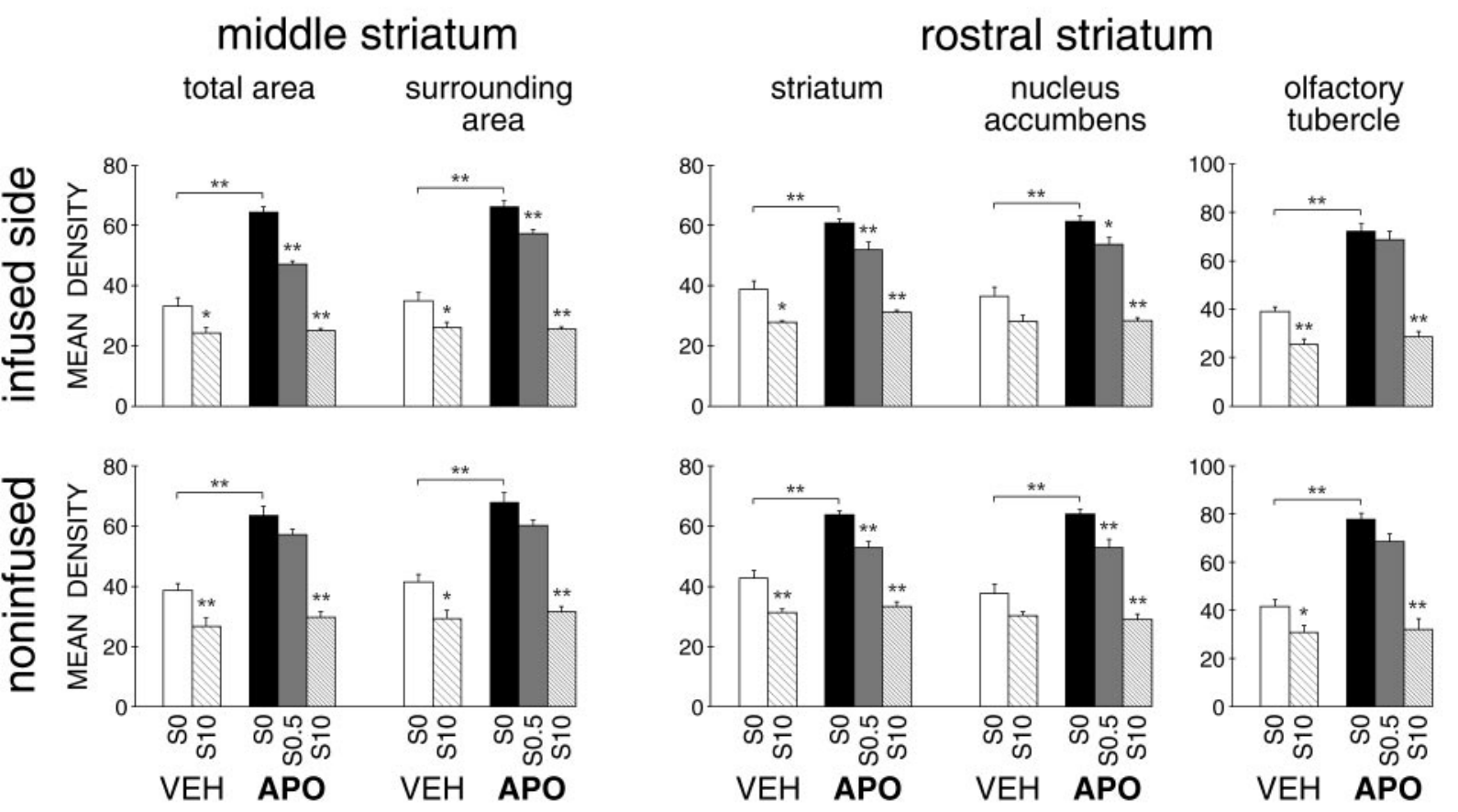

Figure 4. Expression of zif $268 \mathrm{mRNA}$ in the striatum, nucleus accumbens, olfactory tubercle, and cortex after dopamine agonist/antagonist treatments. $A$, Illustrations of film autoradiograms show zif 268 expression in coronal sections from rostral (top) and middle (bottom) striatal levels in rats that received an infusion of vehicle $(S O), 0.5 \mu \mathrm{g}(S 0.5)$, or $10 \mu \mathrm{g}(S 10)$ of SCH-23390 into the right striatum before an injection of vehicle (VEH) or apomorphine $(3 \mathrm{mg} / \mathrm{kg}$, s.c.; $A P O)$. $B$, Mean density values (mean $\pm \mathrm{SEM}$ ) measured in the striatum, nucleus accumbens, and olfactory tubercle on the inf used (top) and noninf used (bottom) sides, at middle or rostral striatal levels, are depicted for the above treatment groups ( $n=4-6$ each). For areas, see Figure 1. ${ }^{*} p<0.05, * * p<0.01$.

Infusion of SCH-23390 into the middle striatum significantly reduced basal levels and blocked the apomorphine-induced increase in expression of c-fos and zif 268 mRNAs in a dosedependent manner. This inhibition of gene expression was uniform throughout the striatum and was also present in the nucleus accumbens and olfactory tubercle. Moreover, although administered unilaterally, the D1 antagonist produced bilateral inhibition. Densitometrical analysis confirmed that the higher dose of SCH-23390 $(10 \mu \mathrm{g})$ completely prevented the immediate-early gene response to the subsequent apomorphine administration; c-fos and zif 268 mRNA levels were comparable with those in controls that received SCH-23390 only. The lower dose of SCH$23390(0.5 \mu \mathrm{g})$ blocked gene induction in a distinct region around the track created by the dummy cannula (Figs. 3, 4). This region covered approximately one-third to one-half of the crosssectional area of the striatum but was irregular in shape, similar to the spread of drug effects seen in previous studies using intrastriatal drug administration (Steiner and Gerfen, 1995, 1999). However, the inhibition of gene expression produced by the lower dose was not restricted to this primary area of drug action but was also observed in the surrounding striatal tissue at the midstriatal level and in the rostral and caudal striatum distant 

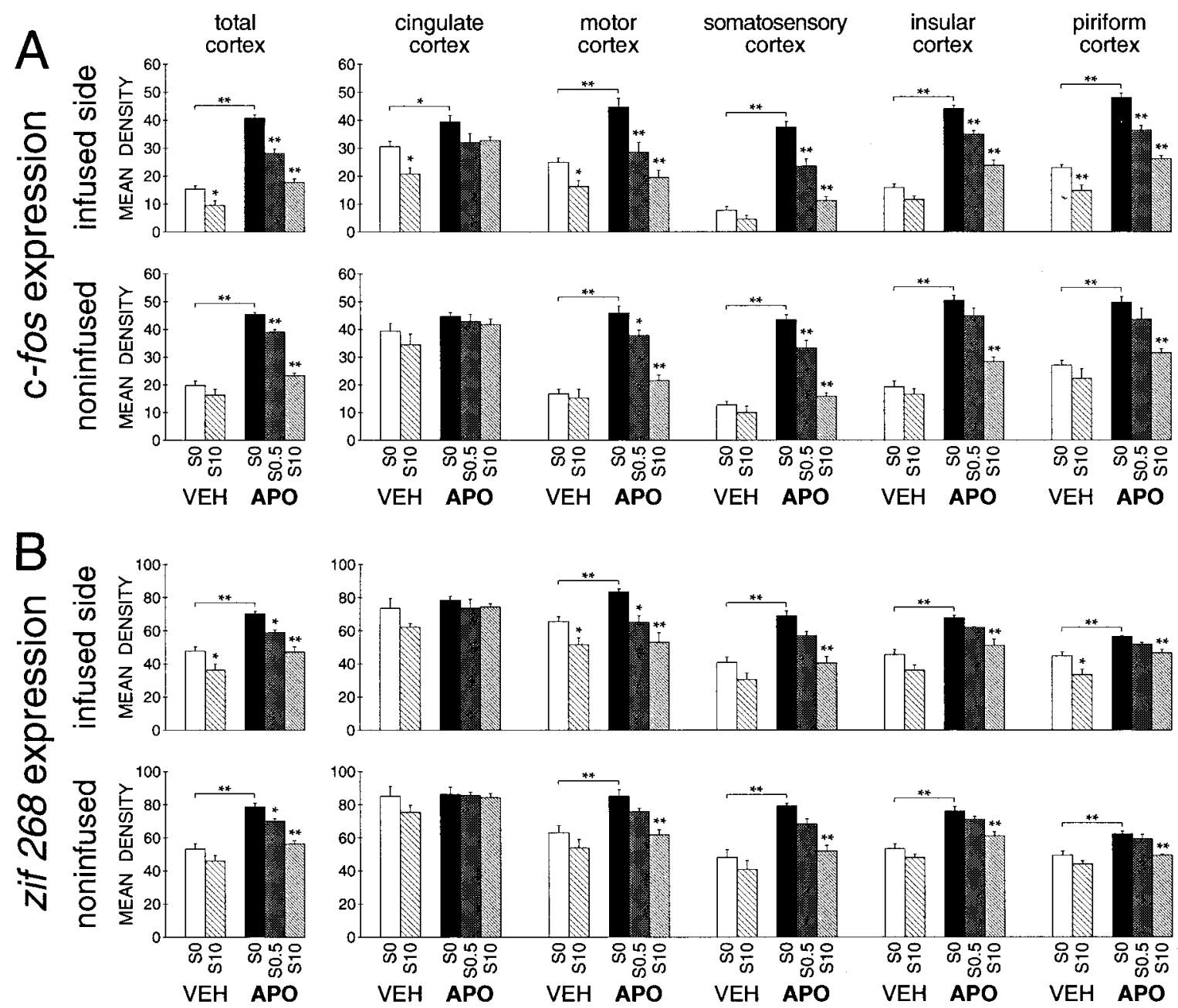

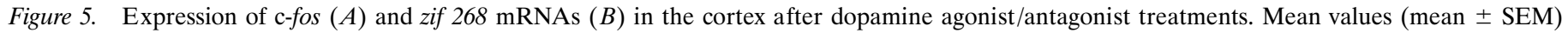

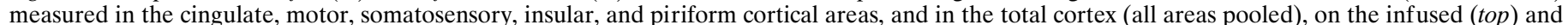

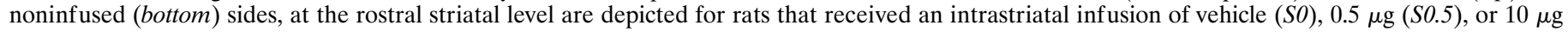

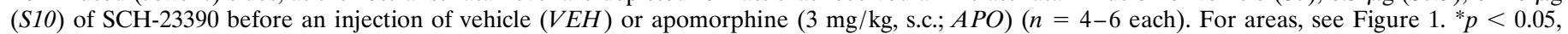
$* * p<0.01$.

from the infusion site. Moreover, this effect was equally robust in the nucleus accumbens but was reduced in the adjacent olfactory tubercle (Figs. 3, 4). Such inhibition of apomorphine-induced gene expression by the lower dose of SCH-23390 was also present in the noninf used hemisphere.

\section{Gene expression in the cortex}

Effects of apomorphine and SCH-23390 treatments on immediate-early gene expression in the cortex at the rostral and middle striatal level can be seen in Figures 3-5. Numerical data for the middle level were similar to those for the rostral level (Fig. 5) and are thus not shown. As was the case in the striatum, principally similar effects were found for c-fos and zif 268 mRNAs in the cortex, but those for c-fos were more robust because of the greater dynamic range for this immediate-early gene (lower basal expression).

Generally, the effects of these drugs on gene expression in the cortex paralleled those on gene expression in the striatum, except for the cingulate cortex. Thus, apomorphine administration considerably increased the expression of c-fos and zif 268 mRNAs in the motor, somatosensory, insular, and piriform cortices. Intrastriatal infusion of SCH-23390 attenuated this response in a dose-dependent manner. This D1 antagonist-mediated inhibition of cortical gene expression was again present in both hemispheres but tended to be more robust on the side of the infusion, especially for the lower dose of SCH-23390 (Figs. 3-5). Interestingly, the cingulate cortex, which showed the highest basal levels of immediate-early gene expression besides layer 2 of the piriform cortex, displayed little or no effects of dopamine agonist/antagonist treatments, consistent with earlier findings (LaHoste et al., 1996).

SCH-23390 has also some affinity for serotonin receptor subtypes (Bischoff et al., 1988; Alburges et al., 1992), and blockade of such receptors may thus have contributed to the effects of the higher dose $(10 \mu \mathrm{g})$. Therefore, it is important to note that the lower dose of SCH-23390 $(0.5 \mu \mathrm{g})$, which is at the lower end of dose ranges generally used to block D1 receptors (Caine et al., 1995; Neisewander et al., 1995; Baker et al., 1998; Epping-Jordan et al., 1998; Mayorga et al., 1999), was sufficient to significantly 
Table 1. Expression of c-fos and zif 268 mRNAs in the striatum, nucleus accumbens, and olfactory tubercle after apomorphine/SCH-23390 treatments (experiment 2)

\begin{tabular}{|c|c|c|c|c|c|c|c|c|}
\hline & \multicolumn{4}{|c|}{ Infused side } & \multicolumn{4}{|c|}{ Noninfused side } \\
\hline & So V & So A & S0.5 A & S10 A & So V & S0 A & S0.5 A & S10 A \\
\hline \multicolumn{9}{|l|}{ c-fos expression } \\
\hline \multicolumn{9}{|l|}{ Middle striatum } \\
\hline Total area & $2.5 \pm 0.6$ & $26.3 \pm 2.7^{\# \#}$ & $12.6 \pm 0.7^{* *}$ & $1.8 \pm 0.9^{* *}$ & $2.5 \pm 0.5$ & $25.3 \pm 3.5^{\# \#}$ & $17.8 \pm 0.7^{*}$ & $2.3 \pm 1.3^{* *}$ \\
\hline Surrounding area & $2.8 \pm 0.5$ & $25.5 \pm 3.1^{\# \#}$ & $17.0 \pm 0.7^{*}$ & $1.3 \pm 0.9^{* *}$ & $1.5 \pm 0.5$ & $24.5 \pm 4.2^{\# \#}$ & $16.2 \pm 0.6$ & $1.8 \pm 1.6^{* *}$ \\
\hline \multicolumn{9}{|l|}{ Rostral striatum } \\
\hline Striatum & $2.8 \pm 0.8$ & $20.0 \pm 1.5^{\# \#}$ & $16.0 \pm 1.1$ & $2.0 \pm 0.4^{* *}$ & $2.8 \pm 0.5$ & $20.8 \pm 1.0^{\# \#}$ & $17.4 \pm 0.7^{*}$ & $2.8 \pm 0.9^{* *}$ \\
\hline Nucleus accumbens & $4.8 \pm 0.6$ & $29.3 \pm 4.2^{\# \#}$ & $17.0 \pm 1.4^{* *}$ & $4.3 \pm 0.5^{* *}$ & $5.0 \pm 1.6$ & $26.5 \pm 4.3^{\# \#}$ & $18.8 \pm 1.2$ & $5.8 \pm 0.9^{* *}$ \\
\hline Olfactory tubercle & $8.5 \pm 2.1$ & $35.3 \pm 1.8^{\# \#}$ & $29.2 \pm 3.3$ & $8.5 \pm 1.0^{* *}$ & $7.5 \pm 1.3$ & $36.5 \pm 4.5^{\# \#}$ & $31.6 \pm 1.9$ & $8.8 \pm 1.6^{* *}$ \\
\hline \multicolumn{9}{|l|}{ zif 268 expression } \\
\hline \multicolumn{9}{|l|}{ Middle striatum } \\
\hline Total area & $24.8 \pm 1.5$ & $56.8 \pm 2.5^{\# \#}$ & $36.2 \pm 1.2^{* *}$ & $24.5 \pm 2.2^{* *}$ & $28.8 \pm 1.7$ & $55.3 \pm 3.3^{\# \#}$ & $44.6 \pm 1.0^{* *}$ & $28.3 \pm 1.4^{* *}$ \\
\hline Surrounding area & $24.8 \pm 1.3$ & $56.0 \pm 3.9^{\# \#}$ & $42.6 \pm 1.8^{* *}$ & $24.3 \pm 2.1^{* *}$ & $26.3 \pm 1.9$ & $55.0 \pm 3.6^{\# \#}$ & $42.8 \pm 1.0^{* *}$ & $27.5 \pm 1.7^{* *}$ \\
\hline \multicolumn{9}{|l|}{ Rostral striatum } \\
\hline Striatum & $30.5 \pm 2.4$ & $51.8 \pm 3.7^{\# \#}$ & $39.8 \pm 1.3^{* *}$ & $29.0 \pm 1.7^{* *}$ & $35.5 \pm 1.7$ & $51.8 \pm 3.1^{\# \#}$ & $41.4 \pm 1.2^{*}$ & $30.0 \pm 2.1^{* *}$ \\
\hline Nucleus accumbens & $36.0 \pm 4.4$ & $69.0 \pm 4.3^{\# \#}$ & $52.2 \pm 2.1^{* *}$ & $31.5 \pm 1.2^{* *}$ & $39.0 \pm 5.2$ & $60.5 \pm 6.6^{\# \#}$ & $52.6 \pm 4.2$ & $34.0 \pm 2.9^{* *}$ \\
\hline Olfactory tubercle & $32.0 \pm 3.8$ & $52.3 \pm 0.8^{\# \#}$ & $52.6 \pm 3.2$ & $29.3 \pm 2.3^{* *}$ & $33.0 \pm 3.8$ & $56.5 \pm 4.1^{\# \#}$ & $55.2 \pm 2.0$ & $31.5 \pm 2.1^{* *}$ \\
\hline
\end{tabular}

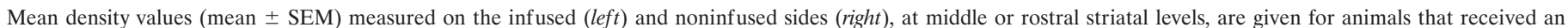

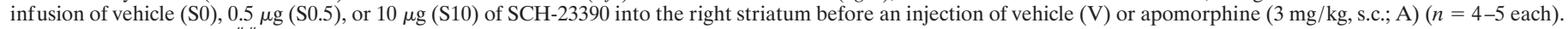
For areas, see Figure $1 .{ }^{\# \#} p<0.01$ versus S0 V; ${ }^{*} p<0.05,{ }^{* *} p<0.01$ versus S0 A.

inhibit apomorphine-induced gene expression in striatum and cortex, indicating a primary role of D1 (or D1-like) receptors (see also Waddington, 1986).

\section{Experiment 2}

\section{Behavioral observations}

After apomorphine administration, rats displayed the typical intense, repetitive sniffing, as well as some licking. Within minutes of infusion of either dose of SCH-23390, a tendency for ipsiversive turning appeared. In animals that received $0.5 \mu \mathrm{g}$, ipsiversive turning behavior remained present or became more pronounced after the subsequent apomorphine injection. In contrast, rats receiving the higher dose of $\mathrm{SCH}-23390(10 \mu \mathrm{g})$ soon became almost completely inactive for the rest of their survival period.

Normal rats tolerate whisker stimulation well. They usually settle down in the relatively small stimulation chamber within a few minutes, often in a position more or less parallel to the longitudinal axis of the cylindrical chamber (and the magnetic field), which enables unimpeded deflection of the stimulated whisker in approximately rostrocaudal direction. In contrast, after apomorphine administration, stimulation of the left whisker C2 induced attempts to turn toward the stimulated (left) side. Although varying in intensity between animals, in extreme cases, this response was so strong that the rat rolled over to the left, partly as a result of the confinement of the chamber. Still, these rats did not try to remove the filament. Such turning could be switched on or off by switching the magnetic field on or off. Some turning was also seen in animals that had received an intrastriatal infusion of $0.5 \mu \mathrm{g}$ of $\mathrm{SCH}-23390$ but never in rats with $10 \mu \mathrm{g}$, which usually sat still for most of the time. As a consequence of this turning response, rats treated with only apomorphine most likely received less constant or unrestricted stimulation of whisker $\mathrm{C} 2$ than vehicle controls or rats with the higher SCH-23390 dose.
Gene expression in the striatum, nucleus accumbens, and olfactory tubercle

The effects of apomorphine and intrastriatal SCH-23390 treatments on immediate-early gene expression in the middle and rostral striatum, nucleus accumbens, and olfactory tubercle are presented in Table 1. As was seen in the first experiment, apomorphine administration increased c-fos and zif 268 expression in these areas, and a preceding intrastriatal infusion of SCH-23390 inhibited this response in a dose-dependent manner in both hemispheres. Again, the lower dose of SCH-23390 (0.5 $\mu \mathrm{g})$ reduced apomorphine-induced immediate-early gene expression throughout the striatum and nucleus accumbens, in addition to blocking this response in a distinct area around the infusion track.

\section{Gene expression in the cortex}

Figure 6 depicts the effects of dopamine agonist and antagonist treatments on whisker stimulation-evoked c-fos and zif 268 expression in layer IV of the barrel cortex. Stimulation of whisker $\mathrm{C} 2$ evoked immediate-early gene expression in contralateral barrel C2 in a discontinuous, punctuate manner, as described previously (Melzer and Steiner, 1997). Such gene expression was not entirely restricted to barrel C2 ("principal" barrel). Labeling spread to some degree into the septa between $\mathrm{C} 2$ and adjacent barrels, mostly along the $\mathrm{C}$ row (Fig. 6).

Consistent with earlier findings (Steiner and Gerfen, 1994), apomorphine had no effect on gene expression in the surrounding, sensory-deprived barrels (Fig. 6). In contrast, in barrel C2, apomorphine administration increased stimulation-evoked immediate-early gene expression. Infusion of SCH-23390 into the ipsilateral striatum attenuated this increase in a dose-dependent manner (Fig. 6). This result was obtained for both c-fos and zif 268 expression but was less variable for c-fos.

\section{DISCUSSION}

Our most important findings include the following. (1) Intrastriatal administration of the D1 receptor antagonist SCH-23390 


\begin{abstract}
Figure 6. Expression of c-fos and zif 268 mRNAs in the barrel cortex after dopamine agonist/antagonist treatments followed by whisker stimulation. $A$, Illustrations of film autoradiograms depict c-fos expression in barrel $\mathrm{C} 2$ in tangential sections through layer IV of the right barrel cortex (top). Barrels were located by cytochrome oxidase activity in adjacent sections (bottom). Rats received an ipsilateral intrastriatal inf usion of vehicle or SCH-23390 [10 $\mu \mathrm{g} ; \mathrm{SCH} 10$ $\mu g$ (i.s.)], followed by vehicle or apomorphine (3 $\mathrm{mg} / \mathrm{kg}$, s.c.; $A P O)$ administration and had contralateral whisker $\mathrm{C} 2$ stimulated for $15 \mathrm{~min}$ with a pulsating magnetic field or were placed in the stimulation chamber without the magnetic field switched on (no stimulation). All other mystacial whiskers were clipped close to the skin. Note also that apomorphine did not increase c-fos expression in neighboring (sensory-deprived) barrels (Steiner and Gerfen, 1994). B, Mean density values (mean \pm SEM) for c-fos and zif 268 mRNA expression in barrel $\mathrm{C} 2$ are shown for animals that received an intrastriatal infusion of vehicle (SO), $0.5 \mu \mathrm{g}(S O .5)$, or $10 \mu \mathrm{g}(S 10)$ of SCH-23390, followed by apomorphine $(3 \mathrm{mg} / \mathrm{kg}$, s.c.) and had contralateral whisker $\mathrm{C} 2$ stimulated for $15 \mathrm{~min}$ $(n=4-5$ each). Controls received intrastriatal and systemic vehicle, followed by $\mathrm{C} 2$ stimulation (only) $(n=2)$ or were not stimulated $(n=2)$. Values presented are the difference between the $\mathrm{C} 2$ value and averaged values measured for the surrounding barrels (background correction). ${ }^{*} p<0.05 ;{ }^{* *} p<0.01$.
\end{abstract}

A

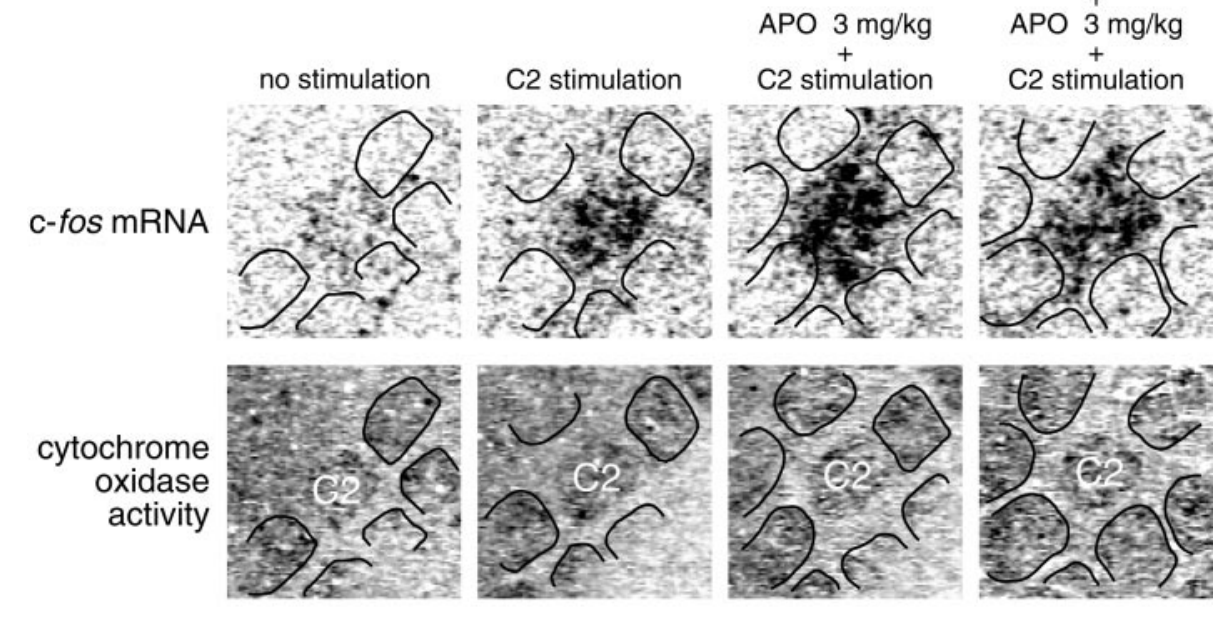

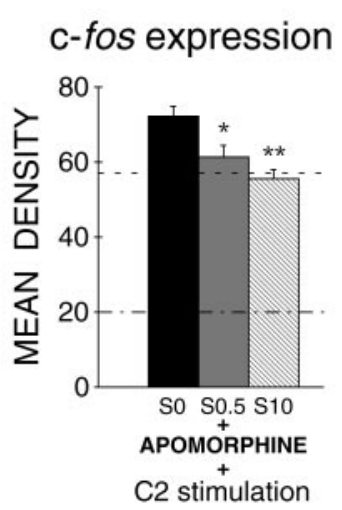

zif 268 expression

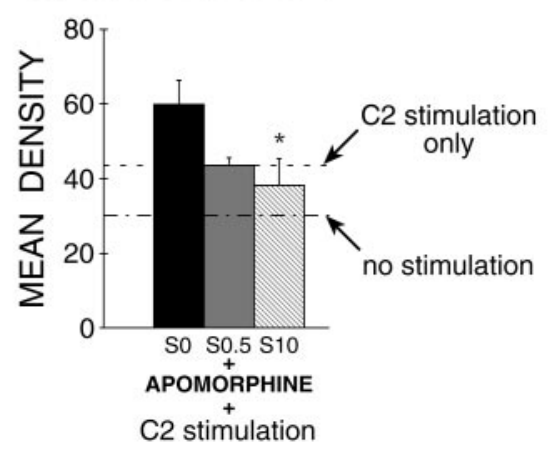

inhibited immediate-early gene induction by the mixed D1/D2 receptor agonist apomorphine throughout the cortex in a relatively uniform manner. (2) Even apparently regionally restricted blockade of striatal D1 receptors had widespread effects in the cortex and throughout the striatum. (3) Intrastriatal administration of SCH-23390 attenuated apomorphine-induced increases in whisker stimulation-evoked immediate-early gene expression in the sensorimotor cortex. (4) This D1 antagonist treatment also inhibited apomorphine-induced sniffing/whisking and turning toward whisker stimulation but not other behaviors. Together, our results suggest that $\mathrm{D} 1$ receptors in the striatum exert a powerful facilitatory influence on cortical function and sensorimotor responsiveness.

\section{Role of striatal D1 receptors in gene regulation in the cortex}

Unilateral intrastriatal infusion of both doses of SCH-23390 resulted in rather uniform inhibition of c-fos and zif 268 expression in both hemispheres. This widespread effect raises the question as to the site of action of the intrastriatally administered drug, a question that is critical for the interpretation of our findings.

Several findings argue for the involvement of striatal D1 receptors and against a major contribution of antagonist leakage to extrastriatal sites. For example, it is unlikely that extensive distribution of the antagonist by blood transport or diffusion into the ventricle contributed to the widespread inhibition of gene expression. Recent studies used receptor autoradiography to examine the spread of SCH-23390 binding in striatal tissue after infusion of up to $3 \mu \mathrm{g}$ into the nucleus accumbens/rostral striatum (Neisewander et al., 1995; Baker et al., 1998). These studies showed relatively confined distribution of SCH-23390 binding around the infusion site. Similarly, in our study, $0.5 \mu \mathrm{g}$ of SCH-23390 blocked striatal gene induction in a distinct area around the cannula track, and in none of the animals that received this dose did this area reach the lateral ventricle or extrastriatal regions. Yet, these animals showed significantly attenuated gene expression bilaterally in the cortex and in striatal areas remote from the infusion site (e.g., in the nucleus accumbens).

There are also D1 receptors in the rat sensorimotor cortex [although orders of magnitude less than in the striatum (Fremeau et al., 1991; Mansour et al., 1992; Gaspar et al., 1995)], and we cannot exclude the possibility of D1 antagonist leakage along the guide cannula into the overlying cortex. However, a principal role of cortical D1 receptors in the widespread, rather uniform effects on gene expression appears unlikely. For one, in our study, both low and high doses of SCH-23390 had qualitatively similar inhibitory effects on gene expression in the cortex, with very little withingroup variability, which seems incompatible with effects of longdistance diffusion. Second, recent studies that investigated immediate-early gene expression after extensive unilateral electrical or chemical stimulation of the motor cortex at sites that partly overlapped with our cannula placement reported principally different patterns of gene induction in cortex and striatum than seen in our study. These studies showed focal induction in the contralat- 
eral cortex and in the lateral striatum ipsilateral and contralateral to the stimulation (Berretta et al., 1997; Sgambato et al., 1999), consistent with the topographical organization of crossed and uncrossed corticostriatal and crossed corticocortical projections.

In contrast, our finding of widespread inhibition of apomorphineinduced immediate-early gene expression by intrastriatal $\mathrm{SCH}$ 23390 is similar to effects observed after stimulation of striatal $\kappa$-opioid receptors (Steiner and Gerfen, 1995). Thus, unilateral intrastriatal infusion of the $\kappa$ agonist spiradoline attenuated cocaine-induced immediate-early gene expression bilaterally in cortex and striatum in a dose-dependent manner (Steiner and Gerfen, 1995). Because cocaine-induced immediate-early gene expression in the striatum is also mediated by D1 receptors (Graybiel et al., 1990; Steiner and Gerfen, 1995; Drago et al., 1996), the results of both of our studies suggest that blockade of D1 receptor responses in the striatum has widespread inhibitory effects on cortical function.

\section{Contribution of sensorimotor feedback to cortical gene expression}

It is possible that altered sensory input, as a consequence of altered behavior, contributed to changes in gene regulation in the cortex after these drug treatments. For example, increased immediate-early gene expression in the barrel cortex after apomorphine treatment is dependent on whisker input (Steiner and Gerfen, 1994). Thus, apomorphine-induced sniffing/whisking likely enhanced the signal seen in this area. However, the apparent dissociation between behavioral activation and gene expression in the cortex (and striatum) observed in animals that received the lower dose of SCH-23390 suggests that such gene expression does not simply reflect behavioral activity. Thus, gene induction in the cortex (and striatum) was significantly reduced in these animals, yet they did not show a clear reduction in any of the behavioral measures (and even displayed more turning). These results indicate that alterations in sensory input could contribute to some, but cannot fully account for all, of the changes in gene regulation in the cortex seen after these drug treatments.

\section{Regulation of gene expression in cortex and striatum by basal ganglia-cortico-basal ganglia circuits}

Our results indicate that decreased stimulation of D1 receptors in the striatum results in widespread inhibition of gene expression in the cortex and that this reflects reduced cortical activity. In the striatum, D1 receptors are predominantly expressed by striatonigral neurons (Gerfen et al., 1990; Le Moine et al., 1991; Le Moine and Bloch, 1995). Consistently, colocalization studies showed that treatments with selective D1 (Robertson et al., 1990; Robertson et al., 1992; Gerfen et al., 1995), mixed D1/D2 (Cenci et al., 1992), or indirect agonists such as cocaine or amphetamine (Cenci et al., 1992; Johansson et al., 1994; Kosofsky et al., 1995) induce immediate-early genes principally in striatonigral neurons. In contrast, immediate-early genes in striatopallidal neurons are induced by blockade of D2 receptors (Robertson and Fibiger, 1992; Robertson et al., 1992). Thus, dopamine/agonist-induced immediate-early gene expression is a response to D1 receptor stimulation in striatonigral neurons. Based on findings on the trans-synaptic regulation of such genes (Sagar et al., 1988; Dragunow and Faull, 1989; Chaudhuri et al., 1995) and transmitter release (You et al., 1994), such gene induction presumably reflects facilitation of neuronal activity in striatonigral neurons.

There are various possible anatomical routes by which in- creased activity in the striatonigral pathway could affect the cortex. For example, nigrothalamocortical pathways provide widespread cortical afferents. In the rat, nigrothalamic neurons project predominantly to the ventromedial ("motor") nucleus and to intralaminar and midline ("nonspecific") nuclei (Faull and Mehler, 1978; Beckstead et al., 1979; Gerfen et al., 1982; Sakai et al., 1998). These connections are to some degree bilateral (Gerfen et al., 1982). Both types of thalamic nuclei provide widespread projections to the cortex (Herkenham, 1979, 1980; Arbuthnott et al., 1990; Groenewegen and Berendse, 1994) and thus seem good candidates for transmitting basal ganglia output "globally" to the cortex.

Altered cortical activities were likely conveyed back to the striatum (Berretta et al., 1997; Sgambato et al., 1999) by the prominent uncrossed and crossed corticostriatal pathways (Webster, 1961; Donoghue and Kitai, 1981; Donoghue and Herkenham, 1986; Wilson, 1987; McGeorge and Faull, 1989; Berendse et al., 1992). Moreover, it has been shown that removal of cortical input or glutamate receptor blockade inhibits dopamine receptormediated changes in gene expression in the striatum (Cenci and Björklund, 1993; Wang et al., 1994a,b; Vargo and Marshall, 1995; Konradi et al., 1996). Therefore, inhibition of apomorphineinduced immediate-early gene expression in striatal regions distant from the site of primary D1 antagonist action (e.g., in the nucleus accumbens) probably reflects reduced excitatory inputs to those areas as a consequence of reduced cortical (or thalamic) activity. Our results thus suggest that regionally restricted functional changes in the striatum indirectly affect large portions of the striatum by a feedforward mechanism involving basal ganglia-cortico-basal ganglia circuits. Moreover, this feedforward mechanism seems to enable interactions between striatal subregions generally thought to be part of functionally distinct circuits, such as the dorsolateral ("sensorimotor") striatum and the ("limbic") nucleus accumbens. It remains to be seen what the functional significance of such interactions is (e.g., synchronization of activity levels) and whether specific cortical inputs to the striatum are involved.

\section{D1 receptors regulate sensorimotor responsiveness}

Acute dopamine depletion produces behavioral deficits, including akinesia and a deficit in sensorimotor responsiveness (for review, see Schwarting and Huston, 1996). For example, rats with unilateral dopamine depletion display a loss of responsiveness ("inattention") to stimulation of the body surface contralateral to the lesion and turning away from that side. Such animals show decreased "basal" and whisker stimulation-evoked expression of immediate-early genes mostly in the cortex ipsilateral to dopamine depletion (H. Steiner and S. T. Kitai, unpublished observations).

On the other hand, dopamine agonist treatments produce repetitive sniffing/whisking and exaggerated responsiveness to sensory input. Thus, under such drugs, unilateral tactile stimulation of the perioral area triggers responding (biting) (Huston et al., 1980) or turning (Steiner and Huston, 1992) toward the stimulus, whereas unilateral removal of whisker input elicits turning or preferential responding toward the opposite, sensory-intact side (Szechtman, 1983; Steiner et al., 1986; Milani et al., 1990). In the present study, under apomorphine, stimulation of a single whisker induced turning toward the stimulated side. Such sensorimotor responding may represent "compulsive orienting" to sensory input as a consequence of abnormally strong dopamine receptor stimulation (Redgrave et al., 1999). 
Our present findings indicate a critical role for striatal D1 receptors (and the direct output pathway) in such dopamine agonist-induced sensorimotor responsiveness. Intrastriatal infusion of the lower dose of the D1 antagonist produced an asymmetrical blockade of D1 receptor responses (more pronounced inhibition of apomorphine-induced gene expression in the striatum and cortex on the inf used side) and caused turning away from the more affected, contralateral periphery (toward the infused side). The higher dose of SCH-23390 blocked striatal and cortical gene induction bilaterally, presumably mediated by basal gangliacortical circuits, and almost completely inhibited apomorphineinduced whisking/sniffing and responding (turning) toward whisker stimulation. In contrast, no comparable inhibition was seen for locomotion (distance, stepping) after SCH-23390 plus apomorphine treatment. Therefore, stimulation of D2 (or D2-like) receptors seems to be sufficient to maintain such motor activities. These results suggest that D1 receptors in the striatum preferentially regulate responding to sensory input, perhaps by affecting attentional or motivational processes, whereas D2 receptors may be more important for other motor functions.

\section{Conclusions}

Our results suggest that local stimulation of striatal D1 receptors facilitates activity in large parts of the cortex (and striatum) through basal ganglia-cortical circuits. Moreover, such facilitation seems to be necessary for normal function of the cortex and for responding to sensory input.

\section{REFERENCES}

Abercrombie ED, DeBoer P (1997) Substantia nigra D1 receptors and stimulation of striatal cholinergic interneurons by dopamine: a proposed circuit mechanism. J Neurosci 17:8498-8505.

Albin RL, Young AB, Penney JB (1989) The functional anatomy of basal ganglia disorders. Trends Neurosci 12:366-375.

Alburges ME, Hunt ME, McQuade RD, Wamsley JK (1992) D1receptor antagonists: comparison of [3H]SCH39166 to [3H]SCH23390. J Chem Neuroanat 5:357-366.

Alexander GE, Crutcher MD, DeLong MR (1990) Basal gangliathalamocortical circuits: parallel substrates for motor, oculomotor, "prefrontal" and "limbic" functions. Prog Brain Res 85:119-146.

Arbuthnott GW, MacLeod NK, Maxwell DJ, Wright AK (1990) Distribution and synaptic contacts of the cortical terminals arising from neurons in the rat ventromedial thalamic nucleus. Neuroscience 38:47-60.

Baker DA, Fuchs RA, Specio SE, Khroyan TV, Neisewander JL (1998) Effects of intraaccumbens administration of SCH-23390 on cocaineinduced locomotion and conditioned place preference. Synapse 30:181-193.

Beckstead RM, Domesick VB, Nauta WJ (1979) Efferent connections of the substantia nigra and ventral tegmental area in the rat. Brain Res 175:191-217.

Berendse HW, Galis-de Graaf Y, Groenewegen HJ (1992) Topographical organization and relationship with ventral striatal compartments of prefrontal corticostriatal projections in the rat. J Comp Neurol 316:314-347.

Berke JD, Paletzki RF, Aronson GJ, Hyman SE, Gerfen CR (1998) A complex program of striatal gene expression induced by dopaminergic stimulation. J Neurosci 18:5301-5310.

Berretta S, Parthasarathy HB, Graybiel AM (1997) Local release of GABAergic inhibition in the motor cortex induces immediate-early gene expression in indirect pathway neurons of the striatum. J Neurosci 17:4752-4763.

Bischoff S, Heinrich M, Krauss J, Sills MA, Williams M, Vassout A (1988) Interaction of the D1 receptor antagonist SCH 23390 with the central 5-HT system: radioligand binding studies, measurements of biochemical parameters and effects on L-5-HTP syndrome. J Recept Res 8:107-120.
Caine SB, Heinrichs SC, Coffin VL, Koob GF (1995) Effects of the dopamine D-1 antagonist SCH 23390 microinjected into the accumbens, amygdala or striatum on cocaine self-administration in the rat. Brain Res 692:47-56.

Carlsson M, Carlsson A (1990) Interactions between glutamatergic and monoaminergic systems within the basal ganglia-implications for schizophrenia and Parkinson's disease. Trends Neurosci 13:272-276.

Cenci MA, Björklund A (1993) Transection of corticostriatal afferents reduces amphetamine- and apomorphine-induced striatal Fos expression and turning behaviour in unilaterally 6-hydroxydopamine-lesioned rats. Eur J Neurosci 5:1062-1070.

Cenci MA, Campbell K, Wictorin K, Björklund A (1992) Striatal c-fos induction by cocaine or apomorphine occurs preferentially in output neurons projecting to the substantia nigra in the rat. Eur $\mathbf{J}$ Neurosci 4:376-380.

Cepeda C, Levine MS (1998) Dopamine and N-methyl-D-aspartate receptor interactions in the neostriatum. Dev Neurosci 20:1-18.

Chapin JK, Lin C-S (1984) Mapping the body representation in the SI cortex of anesthetized and awake rats. J Comp Neurol 229:199-213.

Chaudhuri A, Matsubara JA, Cynader MS (1995) Neuronal activity in primate visual cortex assessed by immunostaining for the transcription factor Zif268. Vis Neurosci 12:35-50.

Chevalier G, Deniau JM (1990) Disinhibition as a basic process in the expression of striatal functions. Trends Neurosci 13:277-280.

DeLong MR (1990) Primate models of movement disorders of basal ganglia origin. Trends Neurosci 13:281-285.

Dilts RPJ, Helton TE, McGinty JF (1993) Selective induction of Fos and FRA immunoreactivity within the mesolimbic and mesostriatal dopamine terminal fields. Synapse 13:251-263.

Donoghue JP, Herkenham M (1986) Neostriatal projections from individual cortical fields conform to histochemically distinct striatal compartments in the rat. Brain Res 365:397-403.

Donoghue JP, Kitai ST (1981) A collateral pathway to the neostriatum from corticofugal neurons of the rat sensory-motor cortex: an intracellular HRP study. J Comp Neurol 201:1-13.

Drago J, Gerfen CR, Westphal H, Steiner H (1996) D1 dopamine receptor-deficient mouse: cocaine-induced regulation of immediateearly gene and substance $\mathrm{P}$ expression in the striatum. Neuroscience 74:813-823.

Dragunow M, Faull R (1989) The use of c-fos as a metabolic marker in neuronal pathway tracing. J Neurosci Methods 29:261-265.

Epping-Jordan MP, Markou A, Koob GF (1998) The dopamine D-1 receptor antagonist SCH 23390 injected into the dorsolateral bed nucleus of the stria terminalis decreased cocaine reinforcement in the rat. Brain Res 784:105-115.

Faull RL, Mehler WR (1978) The cells of origin of nigrotectal, nigrothalamic and nigrostriatal projections in the rat. Neuroscience 3:989-1002.

Fremeau RT, Duncan GE, Fornaretto M-G, Dearry A, Gingrich JA, Breese GR, Caron MG (1991) Localization of D1 dopamine receptor mRNA in brain supports a role in cognitive, affective, and neuroendocrine aspects of dopaminergic neurotransmission. Proc Natl Acad Sci USA 88:3772-3776.

Gaspar P, Bloch B, Le Moine C (1995) D1 and D2 receptor gene expression in the rat frontal cortex: cellular localization in different classes of efferent neurons. Eur J Neurosci 7:1050-1063.

Gerfen CR (1992) The neostriatal mosaic: multiple levels of compartmental organization. Trends Neurosci 15:133-139.

Gerfen CR, Wilson CJ (1996) The basal ganglia. In: Handbook of chemical neuroanatomy (Swanson LW, Björklund A, Hökfelt T, eds), pp 371-468. Amsterdam: Elsevier.

Gerfen CR, Staines WA, Arbuthnott GW, Fibiger HC (1982) Crossed connections of the substantia nigra in the rat. J Comp Neurol 207:283-303.

Gerfen CR, Engber TM, Mahan LC, Susel Z, Chase TN, Monsma Jr FJ, Sibley DR (1990) $\mathrm{D}_{1}$ and $\mathrm{D}_{2}$ dopamine receptor-regulated gene expression of striatonigral and striatopallidal neurons. Science 250:1429-1432.

Gerfen CR, Keefe KA, Gauda EB (1995) D1 and D2 dopamine receptor function in the striatum: coactivation of D1- and D2-dopamine receptors on separate populations of neurons results in potentiated immediate-early gene response in D1-containing neurons. J Neurosci 15:8167-8176. 
Graybiel AM (1997) The basal ganglia and cognitive pattern generators. Schizophr Bull 23:459-469.

Graybiel AM, Moratalla R, Robertson HA (1990) Amphetamine and cocaine induce drug-specific activation of the c-fos gene in striosomematrix compartments and limbic subdivisions of the striatum. Proc Natl Acad Sci USA 87:6912-6916.

Groenewegen HJ, Berendse HW (1994) The specificity of the "nonspecific" midline and intralaminar thalamic nuclei. Trends Neurosci 17:52-57.

Herkenham M (1979) The afferent and efferent connections of the ventromedial thalamic nucleus in the rat. J Comp Neurol 183:487-517.

Herkenham M (1980) Laminar organization of thalamic projections to the rat neocortex. Science 207:532-535.

Huston JP, Nef B, Papadopoulos G, Welzl H (1980) Activation and lateralization of sensorimotor field for perioral biting reflex by intranigral GABA agonist and by systemic apomorphine in the rat. Brain Res Bull 5:745-749.

Hyman SE, Nestler EJ (1996) Initiation and adaptation: a paradigm for understanding psychotropic drug action. Am J Psychiatry 153:151-162.

Johansson B, Lindström K, Fredholm BB (1994) Differences in the regional and cellular localization of c-fos messenger RNA induced by amphetamine, cocaine and caffeine in the rat. Neuroscience 59:837-849.

Kiyatkin EA, Rebec GV (1999) Striatal neuronal activity and responsiveness to dopamine and glutamate after selective blockade of D1 and D2 dopamine receptors in freely moving rats. J Neurosci 19:3594-3609.

Konradi C, Leveque J-C, Hyman SE (1996) Amphetamine and dopamine-induced immediate early gene expression in striatal neurons depends on postsynaptic NMDA receptors and calcium. J Neurosci 16:4231-4239.

Kosofsky BE, Genova LM, Hyman SE (1995) Substance P phenotype defines specificity of c-fos induction by cocaine in developing rat striatum. J Comp Neurol 351:41-50.

LaHoste GJ, Ruskin DN, Marshall JF (1996) Cerebrocortical Fos expression following dopaminergic stimulation: D1/D2 synergism and its breakdown. Brain Res 728:97-104.

Le Moine C, Bloch B (1995) D1 and D2 dopamine receptor gene expression in the rat striatum: sensitive cRNA probes demonstrate prominent segregation of D1 and D2 mRNAs in distinct neuronal populations of the dorsal and ventral striatum. J Comp Neurol 355:418-426.

Le Moine C, Normand E, Bloch B (1991) Phenotypical characterization of the rat striatal neurons expressing the D1 dopamine receptor gene. Proc Natl Acad Sci USA 88:4205-4209.

Mack KJ, Mack PA (1992) Induction of transcription factors in somatosensory cortex after tactile stimulation. Mol Brain Res 12:141-147.

Mansour A, Meador-Woodruff JH, Zhou Q, Civelli O, Akil H, Watson SJ (1992) A comparison of D1 receptor binding and mRNA in rat brain using receptor autoradiographic and in situ hybridization techniques. Neuroscience 46:959-971.

Mayorga AJ, Trevitt JT, Conlan A, Gianutsos G, Salamone JD (1999) Striatal and nigral D1 mechanisms involved in the antiparkinsonian effects of SKF 82958 (APB): studies of tremulous jaw movements in rats. Psychopharmacology 143:72-81.

McGeorge AJ, Faull RLM (1989) The organization of the projection from the cerebral cortex to the striatum in the rat. Neuroscience 29:503-537.

Melzer P, Steiner H (1997) Stimulus-dependent expression of immediate-early genes in rat somatosensory cortex. J Comp Neurol 380:145-153.

Melzer P, Van der Loos H, Dörfl J, Welker E, Robert P, Emery D, Berrini J-C (1985) A magnetic device to stimulate selected whiskers of freely moving or restrained small rodents: its application in a deoxyglucose study. Brain Res 348:229-240.

Milani H, Schwarting RKW, Kumpf S, Steiner H, Huston JP (1990) Interaction between recovery from behavioral asymmetries induced by hemivibrissotomy in the rat and the effects of apomorphine and amphetamine. Behav Neurosci 104:470-476.

Neisewander JL, O’Dell LE, Redmond JC (1995) Localization of dopamine receptor subtypes occupied by intra-accumbens antagonists that reverse cocaine-induced locomotion. Brain Res 671:201-212.

Parent A, Hazrati LN (1995) Functional anatomy of the basal ganglia. I. The cortico-basal ganglia-thalamo-cortical loop. Brain Res Rev 20:91-127.
Paxinos G, Watson C (1986) The rat brain in stereotaxic coordinates. New York: Academic.

Pierce RC, Kalivas PW (1997) A circuitry model of the expression of behavioral sensitization to amphetamine-like psychostimulants. Brain Res Rev 25:192-216.

Redgrave P, Prescott TJ, Gurney K (1999) The basal ganglia: a vertebrate solution to the selection problem? Neuroscience 89:1009-1023.

Robertson GS, Fibiger HC (1992) Neuroleptics increase c-fos expression in the forebrain: contrasting effects of haloperidol and clozapine. Neuroscience 46:315-328.

Robertson GS, Vincent SR, Fibiger HC (1990) Striatonigral projection neurons contain $\mathrm{D}_{1}$ dopamine receptor-activated c-fos. Brain Res 523:288-290.

Robertson GS, Vincent SR, Fibiger HC (1992) $D_{1}$ and $D_{2}$ dopamine receptors differentially regulate c-fos expression in striatonigral and striatopallidal neurons. Neuroscience 49:285-296.

Rocamora N, Welker E, Pascual M, Soriano E (1996) Upregulation of BDNF mRNA expression in the barrel cortex of adult mice after sensory stimulation. J Neurosci 16:4411-4419.

Sagar SM, Sharp FR, Curran T (1988) Expression of c-fos protein in brain: metabolic mapping at the cellular level. Science 240:1328-1331.

Sakai ST, Grofova I, Bruce K (1998) Nigrothalamic projections and nigrothalamocortical pathway to the medial agranular cortex in the rat: single- and double-labeling light and electron microscopic studies. J Comp Neurol 391:506-525.

Sarter M, Bruno JP (1999) Abnormal regulation of corticopetal cholinergic neurons and impaired information processing in neuropsychiatric disorders. Trends Neurosci 22:67-74.

Schwarting RKW, Huston JP (1996) The unilateral 6-hydroxydopamine lesion model in behavioral brain research. Analysis of functional deficits, recovery and treatments. Prog Neurobiol 50:275-331.

Sgambato V, Maurice N, Besson MJ, Thierry AM, Deniau JM (1999) Effect of a functional impairment of corticostriatal transmission on cortically evoked expression of c-fos and zif 268 in the rat basal ganglia. Neuroscience 93:1313-1321.

Smith Y, Bevan MD, Shink E, Bolam JP (1998) Microcircuitry of the direct and indirect pathways of the basal ganglia. Neuroscience 86:353-387.

Steiner H, Gerfen CR (1993) Cocaine-induced c-fos messenger RNA is inversely related to dynorphin expression in striatum. J Neurosci 13:5066-5081.

Steiner H, Gerfen CR (1994) Tactile sensory input regulates basal and apomorphine-induced immediate-early gene expression in rat barrel cortex. J Comp Neurol 344:297-304.

Steiner H, Gerfen CR (1995) Dynorphin opioid inhibition of cocaineinduced, D1 dopamine receptor-mediated immediate-early gene expression in the striatum. J Comp Neurol 353:200-212.

Steiner H, Gerfen CR (1998) Role of dynorphin and enkephalin in the regulation of striatal output pathways and behavior. Exp Brain Res 123:60-76

Steiner H, Gerfen CR (1999) Enkephalin regulates acute D2 dopamine receptor antagonist-induced immediate-early gene expression in striatal neurons. Neuroscience 88:795-810.

Steiner H, Huston JP (1992) Control of turning behavior under apomorphine by sensory input from the face. Psychopharmacology 109:390-394.

Steiner H, Huston JP, Morgan S (1986) Apomorphine reverses direction of asymmetry in facial scanning after 10 days of unilateral vibrissae removal in rat: vibrissotomy-induced denervation supersensitivity? Behav Brain Res 22:283-287.

Szechtman H (1983) Peripheral sensory input directs apomorphineinduced circling in rats. Brain Res 264:332-335.

Szechtman H, Ornstein K, Teitelbaum P, Golani I (1982) Snout contact fixation, climbing and gnawing during apomorphine stereotypy in rats from two substrains. Eur J Pharmacol 80:385-392.

Vargo JM, Marshall JF (1995) Time-dependent changes in dopamine agonist-induced striatal Fos immunoreactivity are related to sensory neglect and its recovery after unilateral prefrontal cortex injury. Synapse 20:305-315.

Waddington JL (1986) Behavioural correlates of the action of selective D-1 dopamine receptor antagonists. Impact of SCH 23390 and SKF 83566 and functionally interactive D-1:D-2 receptor systems. Biochem Pharmacol 35:3661-3667.

Wang JQ, McGinty JF (1995) Differential effects of D1 and D2 dopa- 
mine receptor antagonists on acute amphetamine- or methamphetamineinduced up-regulation of zif/268 mRNA expression in rat forebrain. J Neurochem 65:2706-2715.

Wang JQ, Daunais JB, McGinty JF (1994a) Role of kainate/AMPA receptors in induction of striatal zif/268 and preprodynorphin mRNA by a single injection of amphetamine. Mol Brain Res 27:118-126.

Wang JQ, Daunais JB, McGinty JF (1994b) NMDA receptors mediate amphetamine-induced upregulation of zif/268 and preprodynorphin mRNA expression in rat striatum. Synapse 18:343-353.

Waszcak BL, Walters JR (1983) Dopamine modulation of the effects of gamma-aminobutyric acid on substantia nigra pars reticulata neurons. Science 220:218-221.
Webster KE (1961) Cortico-striate interrelations in the albino rat. J Anat 95:532-545.

Welker WI (1964) Analysis of sniffing of the albino rat. Behaviour 22:223-244.

Wilson CJ (1987) Morphology and synaptic connections of crossed corticostriatal neurons in the rat. J Comp Neurol 263:567-580.

Wise RA, Bozarth MA (1987) A psychomotor stimulant theory of addiction. Psychol Rev 94:469-492.

You Z-B, Herrera-Marschitz M, Nylander I, Goiny M, O'Connor WT, Ungerstedt U, Terenius L (1994) The striatonigral dynorphin pathway of the rat studied with in vivo microdialysis. II. Effects of dopamine D1 and D2 receptor agonists. Neuroscience 63:427-434. 